\title{
East Asian Technical Cooperation Initiatives in \\ Central America: A Comparative Analysis of Japan and South Korea in Guatemala
}

\author{
Diana Astrid Stelzer ${ }^{1}$
}

\begin{abstract}
This article describes the similarities and differences of Japanese and South Korean technical cooperation approaches in Guatemala. The literature review illustrates the transition from an initially donor-centric results chain approach towards one that is increasingly recipient-balanced due to new cooperation principles such as horizontality and demand-drivenness. Such approaches are mainly fostered by the rise of new emerging donors on the international development cooperation horizon, such as the advocates of South-South Development Cooperation (SSDC).

An analysis based on a framework by the Network of Southern Think Tanks (NeST) concludes that Japanese and Korean technical cooperation approaches are markedly similar, most notably in regard to officially proclaimed technical cooperation standards and commitments. Differences result from the degree of related implementation: Japan achieves higher results based on relative deficiencies in reporting by Korea as well as comparatively shorter bilateral Korean-Guatemalan relations. Similarities are fostered by analogous institutional and project related structures, stemming from an argued learning and simulation approach by Korea from the long-standing experiences of Japan. Lastly, it is argued that the growing assimilation of the traditional and the SSDC concept, as well as the increasing engagement of both countries in triangular cooperation contribute to the identified similarities.
\end{abstract}

Keywords: Technical Cooperation, OECD-DAC, South-South Cooperation, Japan, South Korea, Guatemala.

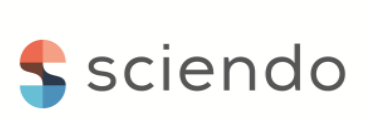

Stelzer, Diana Astrid. 2019. "East Asian Technical Cooperation Initiatives in Central America: A Comparative Analysis of Japan and South Korea in Guatemala." Vienna Journal of East Asian Studies, 11, pp. 92-124.

https://doi.org/10.2478/vjeas-2019-0004

\footnotetext{
${ }^{1}$ I dedicate this article to my beloved father, Rudolf Stelzer, who lived his life with passion, dedication, and diligence towards his goals, inspiring me and others to do alike.
} 


\section{Introduction}

With a growing number of emerging economies moving up the income ladder, in-kind or financial transfers gradually lose relevance in development cooperation discussions in favour of technical cooperation initiatives (Alonso and Glennie 2015: 2). Technical Cooperation (TC) - referring to technical support, consultancies, and the provision of know-how fostering the skills, knowledge and productive aptitude in recipient countries (Tew 2013: 3) - has increasingly made the transition from technical support per se towards capacity building in line with newly defined development principles (Lucas 2013). The related transition from a short-term towards a long-term horizon within the scope of TC initiatives is supported by the international development cooperation agenda (Alonso and Glennie 2015: 2), as well as the increasing interest in South-South Development Cooperation (SSDC) within which project aid, including TC and capacity-building initiatives, accounts for about seventy-five per cent (UN 2014: 2).

Having emerged as an alternative to traditional development cooperation approaches by emerging countries, SSDC has most notably in recent years received increasing attention based on the rise of related key players such as the BRICS (Brazil, Russia, Indonesia, China, and South Africa) and their emerging economies (Gray and Gills 2016: 558). It challenges the development cooperation concept as established by the Development Assistance Committee of the Organisation for Economic Co-operation and Development (DAC-OECD) which defines criteria for official development assistance (ODA) or foreign aid and currently comprises thirty member states from mostly Western or newly industrialised Asian countries, including Japan and South Korea (OECD 2018 [4]).

Asian donors' approaches also reflect changes in the development cooperation landscape and trends towards TC initiatives (The Asia Foundation 2012). This article aims to offer a more comprehensive understanding of the similarities and differences between Japan and South Korea's TC initiative approaches in the Central American Republic of Guatemala. The relevant time frame for analysis is the period after 2010 when both Japan and Korea held DAC-OECD membership (OECD 2018 [2]), creating comparable external circumstances for both case studies to be analysed.

Japan and Korea were selected as case studies given Japan, as one of the DAC's early members, has actively participated from early on in the development cooperation initiatives of international organisations (MOFA 2018 [1]). While Japan can consequently be regarded as a traditional donor, Korea's categorisation is more dubious with references to it as the "Emerging South" (Dahi and Demir 2017: 65) or an emerging market (Bloomberg 2018). Moreover, it is considered a developed country based on trade volume, market, and economy size (Frontera 2016). Furthermore, while Japan can be identified as one of the OECD-DAC's largest donors by volume over the years (OECD 2017), Korea has been recognised as the fifth largest contributor of Southern development aid prior to its DAC membership (Marx and Soares 2013). 
Thus, as a newly industrialised country that only made the jump from an ODA receiver to a DAC member in 2010, Korea is often assigned a special role in development cooperation discussions (Kondoh et al. 2010; Kondoh 2015). Highlighting its own role as a bridge between established and emerging cooperation partners (Jung et al. 2011), Korea continuously builds its foreign policy agenda on the principles of middle-powerism, with the aim of facilitating and catalysing supra-regional cooperation (Faure 2016).

Guatemala serves as a case study as while there is vast research in the field of bilateral development cooperation among Asian and various African countries, related research on Latin American countries is relatively scarce, despite the continuously growing East Asian influence in the region (Maggiorelli 2017: 30). With Guatemala being "one of the strongest economic performers in Latin America in recent years" (The World Bank 2018), the country offers strong potential in the region and is further representative of similar opportunities and challenges which Japan and Korea face in Central America (The World Atlas 2018). Most notably, Guatemala is one of five countries in the Central American region with diplomatic relations with Taiwan as opposed to the People's Republic of China (Maggiorelli 2017: 45). China's growing economic influence is notably slower in Central America as it has been argued that economic interests "would take a backseat in Beijing's diplomatic offensive against Taipei" (Business Insider 2018). Furthermore, given the void which the withdrawal of the United States from the Trans-Pacific Partnership has created, chances are increased for other major trade partners like Japan and Korea to become the next hegemonic economic partner in the Central American region (Naylor 2017).

\section{Literature Review}

The literature review on relevant TC evaluation criteria within development cooperation illustrates the transition from an initially donor-centric results chain approach towards one that is increasingly recipient-balanced due to fundamental cooperation principles such as horizontality and demand-drivenness. These approaches are mainly fostered by the rise of newly emerging donors on the international development cooperation stage. Hand in hand with the new principles and paradigms goes the move from quantitative towards increasingly qualitative measurement approaches in TC. Such a shift is based on the notion that quantitative evaluations only lack the ability to capture non-material factors and are further very sensitive in regard to social differences between countries (Garbarino and Holland 2009). 


\section{Technical Development Cooperation Evaluations along the Results Chain}

The evaluation of development cooperation is traditionally discussed along the results chain and considers inputs, activities, outputs, outcomes, and impacts (see figure 1) (Poate 1997: 6; Holzapfel 2014: 19).

Figure 1: Traditional Results Chain Approach

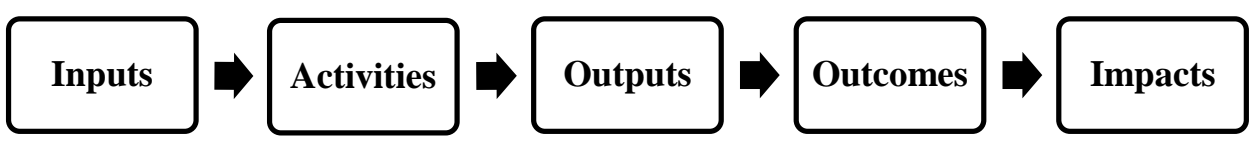

Source: adapted from Holzapfel 2014: 19

In line with this, major international development cooperation organisations have also traditionally adhered to results-based evaluations along the results-chain. For example, the DAC-OECD performs evaluations using the results chain (SAIIA 2015: 22).

Despite its wide use by major international organisations, the results-based approach has faced criticism. For instance, it has been suggested that insufficient attention is paid to the receiver side, making it an instrument for compliance and control (SAIIA 2015: 20-21). The argument is most notably raised by South-South Cooperation representatives who pledge greater horizontality and demand-drivenness based on the principle of non-interference.

\section{South-South Development Cooperation and the Results Chain Approach}

As a sub-category of South-South Cooperation (SSC), South-South Development Cooperation (SAIIA 2015: 12) can broadly be defined as "any exchange of resources, personnel, technology, and knowledge between 'developing' countries" (Vaes and Huyse 2013: 5). Emphasising the inherent blurriness of the concept, Mawdsley (2012 [2]: 63) points out that South-South Cooperation is "a loose definition that can cover almost any form of interaction from South-South foreign direct investment by Asian, African and South-American multinational firms, to diplomatic meetings and agreements, to the provision of technical experts" (ibid.: 63). It is argued that the broadness of the concept is a vital element in capturing the diversity of Southern partnerships, with a focus on South-South Cooperation core values rather than eventual cooperation confining aspects (UNCTAD 2015: 4-5).

In parallel, the growing influence of South-South Cooperation ideas on traditional aid concepts has drawn attention (Tortora 2011: 4). With South-South Cooperation traditionally putting a strong focus on TC initiatives, material influences on traditional concepts in this area are particularly strong. The majority of projects are "demanddriven, pursuing visible and tangible results" (UN 2014: 2), thus reflecting major 
principles of SSDC, including: equality between partners, the fostering of national and collective self-reliance, mutual benefit and voluntary actions, demand-drivenness (FIDC 2014: 1-2), and exerting ideational influence on the traditional results chain approach (Mawdsley 2017: 111).

\section{Ideational Aspects in Development Cooperation Evaluations}

Besides the "Rise of the South" and related South-South cooperation approaches which have fostered interest in related underlying principles within the literature, another major influence on current development cooperation evaluation tendencies can be provided based on high level fora over the past five years.

According to Mawdsley (2017: 110-111), the Fourth High Level Forum on Aid Effectiveness in Busan, Korea in 2012 marks the change from a schedule focused on aid effectiveness to a schedule on development effectiveness (Oxfam 2012: 3). While the emphasis on ownership, results, and accountability was adopted from the principles introduced at the High Level Forum on Aid Effectiveness in Paris in 2005, inclusive partnerships and transparency initiated a new focus in development cooperation (Oxfam 2012: 5). In detail, the four new basic principles include:

1) Ownership of development priorities: Encouraging the self-driven design of development initiatives by recipient countries

2) Focus on results: A focus on outcomes which diminish poverty, foster local capacity, and decrease inequality is envisioned

3) Inclusive partnerships: Taking steps towards mutual learning and trust in development cooperation

4) Transparency and accountability to each other: Clarifying mutual accountability in development cooperation and adopting a transparent approach in service delivery from the donor side (Oxfam 2012: 5).

The Busan declaration was ratified not only by DAC members but also major nonDAC members in the form of "differential" commitments (Oxfam 2012: 5). Thus, a crucial step was taken towards the common acknowledgement of the values of transparency, inclusiveness, mutual accountability, and results; principles which have been promoted by traditional development cooperation partners for a long time. Simultaneously, a number of originally South-South Cooperation principles have been further considered (Tortora 2011: 2).

\section{Towards a Demand-Driven Results Chain Approach}

The newly manifested cooperation principles have resulted in an evolution of the traditional results chain approach, with alternative suggestions being raised in 
cooperation evaluation. This includes most notably the shift from donor-driven development cooperation aims towards an equal focus on demand-driven objectives, thus better meeting the genuine needs in development cooperation by appropriately articulating and defining them (Haider 2008; European Commission 2009). The greater focus on horizontality, ownership, and inclusive partnerships in development cooperation has resulted in efforts to integrate the newly demanded principles into the traditional results chain approach as depicted in figure 2 (SAIIA 2015: 21).

Figure 2: Horizontal Results Chain Approach

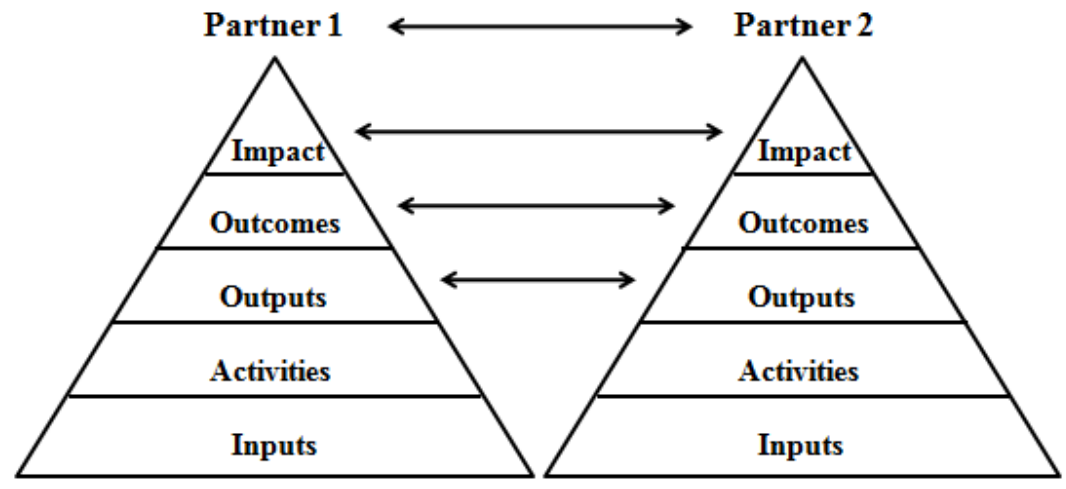

Source: adapted from SAIIA 2015: 21

Efforts towards greater ownership, horizontality, and inclusive partnerships between the donor and receiver further align with a new perspective on the simultaneously pursued results orientation. This approach derives from new cooperation principles which emphasise process-orientation parallel with results-orientation. It contrasts with the previous exclusive focus on the benefit of issues such as long-term capacity building and local ownership (Narasaiah 2003: 37).

The changes are reflected in an amended results-chain approach. In response to the requirement for horizontality, ownership and demand-drivenness stand at the initial stage of the chain, moving to harmonisation issues such as horizontal negotiation and mutual implementation (figure 3). Lastly, the link is made to outcomes and results with a focus on long-term sustainability (European Commission 2009: 27).

Figure 3: Demand-driven Results Chain Approach

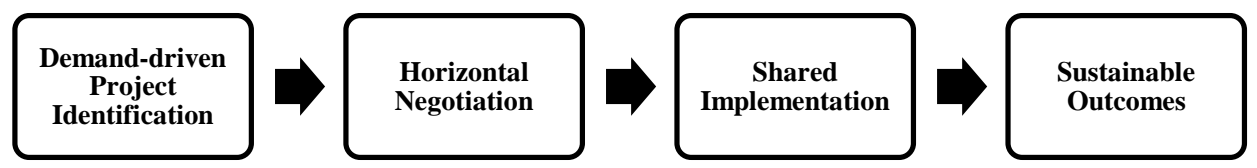

Source: adapted from SEGIB 2010: 107 
The production of new commonly shared development cooperation principles and the related transition towards a demand-driven results chain approach focused on process definitions is strongly reflected in research which strives to translate the principles into measurable indicators (Birdsall and Kharas 2010: 11).

While some research directly employs cooperation principles derived from high level fora for obtaining quality indicators and related sub-criteria (Rosero Moncayo and Zorilla 2013), others develop new dimensions based on the cooperation principles from which relevant indicators are extracted (Birdsall and Kharas 2010: 11; King 2014: 9; De Oliveira 2017: 18).

\section{Translating Cooperation Principles into Relevant Indicators: Focus on Re- sults}

In TC projects, an approach based on effectiveness without any focus on related process evaluations is regarded critically. As Narasaiah (2003: 37) points out, effective and sustainable modes of development cooperation will always entail a focus on processes based on the notion that one-time results achievement remains meaningless as long as related systems and procedures remain unchanged. It is thus argued that an "extended and more analytical, process-oriented definition should take into account four main aspects of aid effectiveness" (Narasaiah 2003: 37), namely: the strengthening of local aid management capacities; local ownership throughout the aid process in the form of setting priorities, policy formulation, implementation, and evaluation; mutual accountability on both the donor and recipient sides; and transparent processes and donor motives as is often reflected in the principle of mutual benefit. Transparency, accountability and ownership were highlighted along with the focus on results in the high level forum meetings (OECD 2018 [1]). As such, the balance of effectiveness and efficiency based approaches for sustainable long-term impact in development cooperation can be regarded as confirmed.

The approach of evaluating efficiency in parallel with the focus on effective outcomes has found resonance in various research projects in which process evaluations are performed alongside results evaluations (SEGIB 2010: 104; De Oliveira 2017: 38). For development processes to support the sought-after results efficiently, some basic discussions can be pointed out around the indicators of flexibility and adaptation of processes, related internal and external coordination systems, as well as time and cost efficiency (Birdsall and Kharas 2010: 16; Baumann 2018: 17).

\section{Ownership}

Discussions of ownership include the call for demand-drivenness and non-conditionality as fundamental tenets (Buiter 2005: 27; Bandura and Hammond 2019: 2). Demand-drivenness includes a wide variety of indicators that touch interconnected 
dimensions such as donor decentralisation, local participation and co-determination, local governance, as well as bottom-up accountability (Jordhus-Lier et al. 2009: 7). Associated TC process-related evaluation discussions extend to consider whether recipients are involved in project planning and implementation after the demand-driven request is responded to and aligned with national priorities (King 2014: 11; De Oliveira 2017: 38). Non-conditionality, on the other hand, can be regarded as an indicator that directly results from recipient ownership and related non-interference principles. While non-conditionality can be claimed as a pre-requisite for long-term sustainability in development cooperation (Selbervik 1999: 5), other researchers have challenged this notion. They have, for instance, asked if conditionality and ownership cannot go hand in hand in light of the political constraints deemed necessary and varying environmental conditions (Montinola 2007).

The measurement of ownership was originally driven by a governmental focus on the relations between donors and recipients (CID 2012: 1). Consequently, research displays an emphasis on the criteria of fostering and supporting recipients' institutions given the aim of successfully enhancing recipient countries' ownership (Birdsall and Kharas 2010: 16). Equally, it has been argued that recipient ownership that overlooks capacity building in technical development cooperation projects will negatively impact the ownership of the recipient country in the long term due to insufficient local skills (Godfrey et al. 2002: 361). The application of related indicators measuring the degree of experience and skill as well as technology transfer occur as a result (Bergström 2002; UNCTAD 2014: 8). Finally, the ownership concept and attendant shift of attention from aid donors to receiving governments and their resource allocation presents leadership problems, particularly with regards to government accountability. However, it fosters the inclusion of new players such as civil society actors, as well as other stakeholders such as marginalised groups (SAIIA 2015: 25). Moreover, it affords greater focus on equality, sustainable development, and work and living conditions in line with human rights standards (CID 2012: 1).

\section{Inclusive Partnerships}

On the most basic level, inclusivity in partnerships refers to the extent to which "relevant actors are involved in planning and implementation" (OECD 2006: 7). The term inclusive partnerships thus simultaneously reflects the relevance of recipient ownership and horizontality in development cooperation partnerships (ibid.: 4) and leads to related analysis in the literature. Evaluating shared governance within inclusive partnerships is a recurring approach within development cooperation assessments. It further links directly to the indicator of collaborative relationships where initially defined aims are realised based on "regular and effective interaction" (King 2014: 11), as well as "joint supervision and monitoring" and "joint responsibility" (Uh and Siddiky 2017: 132). In line with shared governance, mutual trust and solidarity are 
investigated; greater horizontality in decision-making and resource related issues can foster both and thus create greater development efficiency in the long-term based on increased policy influence (Del Biondo 2015: 12). While related recipient perceptions are difficult to capture from an analytical perspective, interest is growing regarding a constructivist understanding of the international aid regime (Kondoh 2015: 13).

Clear communication of mutual benefits to development aid receivers and related indicator-based evaluations aligns with trust building initiatives. Mutual benefit is generally a strongly advocated topic from the SSDC side; it evolved partially based on the deliberate opposition to traditional Western discourses on development assistance, foreign aid as well as charity, focusing instead on mutual benefits, equality, and respect for national ownership and sovereignty (Mawdsley 2012 [1]: 263). Furthermore, with mutual benefit one of the key principles of Chinese governmental development aid alongside "mutual respect for sovereignty and territorial integrity," "mutual non-aggression," "non-interference in each other's internal affairs," as well as "peaceful coexistence" (Van de Looy 2006: 2), the indicator has found resonance in multiple development cooperation frameworks that evaluate development cooperation beyond the DAC principles.

\section{Transparency and Mutual Accountability}

Mutual accountability and transparency are issues that are often handled together, not only by major international organisations but also by the academic literature (Kharas 2013; UNDESA 2018). In line with this tendency in the literature, McGee (2013: 109) points out that "transparency is a necessary but insufficient condition for aid accountability," emphasising that more transparency will not necessarily lead to accountability within development cooperation but that both complement each other. The contribution of transparency can most notably be found in the shifting of principal agent related imbalances (Eyben 2008: 11; Christensen et al. 2011).

In order to measure the related effectiveness of mechanisms within an institutional framework, the data collection, reporting, and usage within the aforementioned data management systems are relevant criteria that have found resonance in the literature (Poate 1997; Park 2017: 2586). Based on a clear understanding of the project outline and the need for related reporting based on appropriate systems and structures, the role of monitoring and evaluation (M\&E) frameworks is emphasised (Birdsall and Kharas 2010: 16). As part of monitoring and evaluation (UNISDR 2013: 3), reporting can be regarded as a process running in parallel to the multiple stages of the project management result chain. Monitoring focuses on the activities/inputs as well as outputs stages and is applied to outcomes and impacts (MFDR 2007: 4; UNDP 2009; UNISDR 2013: 9). Hand in hand goes the question to what extent is the related donor expertise, budget, and time given to perform the respective monitoring and evaluation 
processes (Watson 2006) and whether a learning effect is achieved (Coe and Majot 2013; Wallach et al. 2017).

\section{Methodology}

Based on the investigated relevant criteria for TC, an analytical framework by the Network of Southern Think Tanks was adapted to be applied to the relevant case studies (SAIIA 2017: 11). As Ali (2018: 13) emphasises, although originally intended as a typology for SSDC, the key dimensions describing effectiveness and quality within the NeST framework show remarkable similarities with aid effectiveness principles as described by the DAC-OECD. This can mainly be traced back to the fact that the NeST framework is based on principles from major development cooperation conferences which have themselves experienced a growing assimilation of traditional and South-South Cooperation principles as illustrated in the literature review.

Table 1: Indicators to measure TC Quality

*excluded from the framework to be applied

\begin{tabular}{|c|c|c|c|c|c|}
\hline 哭 & $\begin{array}{l}\text { Inclusive } \\
\text { National } \\
\text { Ownership }\end{array}$ & Horizontality & $\begin{array}{c}\text { Self-Reliance } \\
\& \\
\text { Sustainability }\end{array}$ & $\begin{array}{c}\text { Accountability } \\
\text { \& } \\
\text { Transparency }\end{array}$ & $\begin{array}{c}\text { Development } \\
\text { Efficiency }\end{array}$ \\
\hline \multirow{4}{*}{ 氖 } & $\begin{array}{c}\text { Multi- } \\
\text { Stakeholder } \\
\text { Participation }\end{array}$ & Mutual Benefit & $\begin{array}{l}\text { Capacity } \\
\text { Building }\end{array}$ & $\begin{array}{c}\text { Data } \\
\text { Management \& } \\
\text { Reporting }\end{array}$ & $\begin{array}{c}\text { Flexibility \& } \\
\text { Adaptation }\end{array}$ \\
\hline & $\begin{array}{l}\text { People-Centred } \\
\text { Inclusivity }\end{array}$ & $\begin{array}{c}\text { Shared } \\
\text { Decisions \& } \\
\text { Resources }\end{array}$ & $\begin{array}{c}\text { Use of Country } \\
\text { Systems \& } \\
\text { Human } \\
\text { Resources }\end{array}$ & $\begin{array}{l}\text { Monitoring \& } \\
\text { Evaluation for } \\
\text { Learning }\end{array}$ & $\begin{array}{c}\text { Coordination } \\
\text { (internal \& } \\
\text { external) }\end{array}$ \\
\hline & $\begin{array}{l}\text { Demand- } \\
\text { Drivenness }\end{array}$ & $\begin{array}{c}\text { Solidarity } \\
\& \\
\text { Trust }\end{array}$ & $\begin{array}{c}\text { Knowledge \& } \\
\text { Technology } \\
\text { Transfer }\end{array}$ & $\begin{array}{c}\text { Transparency \& } \\
\text { Access to } \\
\text { Information }\end{array}$ & $\begin{array}{l}\text { Time \& } \\
\text { Cost } \\
\text { Efficiency }\end{array}$ \\
\hline & $\begin{array}{c}\text { Non- } \\
\text { Conditionality }\end{array}$ & $\begin{array}{c}\text { Global Political } \\
\text { Coalitions* }\end{array}$ & $\begin{array}{l}\text { Domestic } \\
\text { Revenue } \\
\text { Generation }\end{array}$ & $\begin{array}{c}\text { Mutual } \\
\text { Accountability \& } \\
\text { Joint Reviews }\end{array}$ & $\begin{array}{c}\text { Policy } \\
\text { Coherence for } \\
\text { Development* }\end{array}$ \\
\hline
\end{tabular}

Source: adapted from SAIIA 2017: 11

As SAIIA (2015: 25) highlights in regard to the NeST framework, "many of the good practices and challenges that affect NSC are also valid for co-operation among Southern partners." Hand in hand goes the notion that "some of the systems to 
measure the effectiveness, efficiency and results of NSC may also be applicable to the monitoring and evaluation of SSC." Consequently, "selected elements and relevant experiences can also be drawn out from the aid effectiveness discourse that can feed into the work currently undertaken with NeST" (SAIIA 2015: 25), in turn justifying the application of the framework to Japan and South Korea - the only non-occidental DAC members.

\section{Analysis}

The following analysis results were based on JICA (Japan International Cooperation Agency) and KOICA's (Korea International Cooperation Agency) TC initiatives in Guatemala. On the Japanese side, a focus was placed on Japan's "Country Assistance Policy Plan for Guatemala" (MOFA 2018 [2]) as well as five major ongoing Japanese TC initiatives, all of which started after 2010 (JICA 2018 [3]). The relevant TC initiatives (JICA 2018 [3]), including one which is loan-enabled, are:

- Project for Maternal and Child Health and Nutrition Improvement in Quiche ○ TC Project (2016/06-2020/06)

- Project on Capacity Development for Disaster Risk Management in Central America

○ TC Project (2015/07-2020/06)

- Project for the Improvement of the Quality of Lower Secondary Mathematics Education ("Guatemática")

○ TC Project (2017/01-2019/07)

- Project for Strengthening of Police Human Resources through the Promotion of Community Police

○ TC Project (2016/06-2019/05)

- Zonapaz Road Improvement Project (II) in Alta Verapaz and Quiche

○ Loan-enabled TC Project (2012/11-not specified).

Guatemala is a non-priority partner; as such, no Korean development cooperation policy agenda exists (ODA Korea 2018 [2]). Focus was thus placed on the following relevant major TC projects (KOICA 2016: 67; KOICA Guatemala 2018 [2]):

- Project for Enhancing the Capacity of the Huehuetenango National Hospital on Maternal and Infant Health [sic].

○ Project Type Cooperation (2011/05-2018/02)

- Project for Increasing Access to and Safety of Portable Water in Huehuetenango Department

○ Project Type Cooperation (2011/05-ongoing) 
- Project for the Improvement of Police Education and Training of National Civil Police

○ Project Type Cooperation (2014/01-ongoing).

\section{Inclusive National Ownership}

\section{i. Multi-Stakeholder Participation}

With both donor countries' shared interest in increasing multi-stakeholder participation based on consideration of this topic within major policy plans, relevant platforms were created and institutional arrangements made by Japan and Korea to increasingly integrate interested parties in related initiatives via public-private programmes or growing dialogues with NGOs, universities or civil society actors (ODA Korea 2017: 126; JICA 2018 [12]: 1). However, despite the great number of available platforms, these new forms of cooperation have only marginally found application within TC initiatives in Guatemala. While public-private programmes with local companies are neither applied Japanese nor Korean TC initiatives, diverging approaches between both donor countries can be identified in the integration of civil society and universities. Korea's approach in Guatemala is marked by relatively regular information exchange with civil society in the form of panel discussions and seminars and limiting the involvement in projects to M\&E processes (KOICA 2011; KOICA Guatemala 2018 [5] [6]). Japan's approach, however, characterises itself by comparatively little regular exchange with civil society (Rocha Menocal and Wild 2012: 2), while evidence for the active involvement of civil society and universities within TC initiatives could be found (Barascout 2015: 32). Based on the analysis, it could further be found that neither Japan nor Korea dedicates special attention to stakeholder issues of gender equality.

\section{ii. People-Centred Inclusivity}

Both countries place strong emphasis on socio-economic people-centricity based on a focus on health and education in their initiatives addressing the most disenfranchised population groups and achieving geographical inclusivity via infrastructural projects beyond urban areas. With both countries' TC approaches targeting maternal and infant health and partially covering indigenous population groups, gender equality also plays a role and aims towards poverty alleviation and social inclusion. Geographic inclusion is achieved by related projects in the infrastructure sector (Barascout 2015: 32; KOICA 2016: 67; MOFA 2018 [2]).

In contrast to Korea, Japanese initiatives additionally reflect a strong focus on meeting sustainability and environment-related standards which are integrated in the assessment of cooperation initiatives (JICA 2018 [6]: 3-4). Integration of affected 
population groups in project planning and implementation could not, on the other hand, be found in Japanese or Korean initiatives.

\section{iii. Demand-Drivenness}

The review has revealed for both donor countries a strong alignment of TC project initiatives with Guatemalan national priorities as outlined in the Guatemalan National Plan for Development K'atun 2032 (UNDP 2015; KOICA Guatemala 2018 [3]; MOFA 2018 [2]). Hand in hand goes a moderate to high level of participation and involvement of Guatemalan officials in related project formulation and development (SEGEPLAN (2018 [1]).

While the link to Guatemala's development strategy is given, the extent to which TC initiatives were triggered by an explicit request from the recipient country remains unclear in most project cases. One of JICA's TC initiatives, Guatemática, resulted from an explicit request from the Guatemalan government (Barascout 2015: 50), yet the assumption of a request-based project formulation in regard to other TC initiatives remains speculative.

\section{iv. Non-Conditionality}

Having evaluated the aspect of non-conditionality within non-loan based Japanese and Korean TC initiatives, no indices for conditionality from either donor county were identified (KOICA 2018 [2]; MOFA 2018 [2]). In reference to loan-based TC initiatives, however, economic conditionality was applied to one KOICA-based TC initiative proposal which, due to local Guatemalan procurement regulations, failed to be implemented (El Periódico 2017).

\section{Horizontality}

\section{i. Mutual Benefit}

Japan's development assistance policy plan limits the mutually obtainable benefits from its cooperation with Guatemala to discussions of improved bilateral relations (MOFA 2018 [2]). The lack of a comparable bilateral cooperation document by KOICA impairs the drawing of conclusions for the Korean case study (ODA Korea 2018 [2]). A published cooperation document by the Guatemalan governmental organisation SEGEPLAN (2018 [1]) on Korean relations, however, emphasises the aim of strengthened bilateral diplomatic relations. Given the evidence of increasing exchanges and high-level visits of both donor countries to Guatemala, the achievement of the targeted diplomatic aims can be regarded as fulfilled (Roblero Morales 2017: 31; MOFA 2018 [3]). 
Efforts illustrating a successful mutual learning approach become visible within a JICA TC initiative originally implemented in Guatemala which was extended to other Central American countries, leveraging mutual lessons learned (JICA 2018 [11]).

\section{ii. Shared Decisions and Resources}

The investigation shows that both countries place emphasis on the mutual outline of aims at the project's initial stage in the form of the establishment of Joint Coordination Committees on the Japanese side (JICA 2016 [1]) and the signature of related mutual agreements on the Korean side (Infile 2018). Evidence is given that initial technical discussions, scoping missions, and joint evaluations are continued throughout the project phase by both donor countries, although Japan and Korea do not provide any documentation on eventual mutual follow-up joint decision-making mechanisms (JICA 2016 [1]; KOICA 2018 [2]).

With regards to relevant interrelated resource allocation matters, while both donor countries put an emphasis on integrating local human resources in their initiatives, the entrusted activities are mainly limited to administrative tasks, while expert and leadership roles are taken by delegated Japanese or Korean personnel (KOICA 2011: 40; Barascout 2015: 47). Regarding financial issues, evaluations of relevant ex post evaluation reports have shown that most of the project costs are borne by the donor countries with Guatemala providing basic project facilities and amenities (Embajada de la República de Corea en Guatemala 2018; JICA 2018 [5]).

\section{iii. Solidarity and Trust}

In contrast to the comparatively long-standing development cooperation relationship with Japan, Korean development cooperation with Guatemala started more recently. The quality of both bilateral relationships can be assessed as high based on frequent communication and interactions on a bilateral as well as a project based level (Roblero Morales 2017: 31; Embajada de Japón en Guatemala 2018). While Japanese-Guatemalan relationships present themselves as limited to regular bilateral exchanges (MOFA 2018 [3]), Korean-Guatemalan relations are additionally fostered on a multilateral level in cooperation with other Central American countries given Korea's increasing emphasis on establishing itself as a middle-power in international relations (The Diplomat 2018).

Common objectives with regards to developmental policy, as well as the tendency towards medium- and long-term relations, is reflected in both donor countries' shared development cooperation interests and objectives in line with Guatemala's National Plan for Development K'atun 2032 (Roblero Morales 2017: 56; MOFA 2018 [2]). 


\section{Self-Reliance and Sustainability}

\section{i. Capacity Building}

No Guatemalan cooperation framework exists on the Korean side and Japan affords only superficial consideration of capacity building initiatives within its cooperation framework for Guatemala (MOFA 2018 [2]). Nevertheless, multiple Japanese and Korean TC initiatives illustrate the relevance of capacity building for both donor countries by fostering core skills beyond short-term project implementation. While Korean TC initiatives regard capacity building as an add-on to the implementation of the main project in relevant sectors (KOICA Guatemala 2018 [1]), JICA comparatively places a stronger focus on capacity building as a primary aim. This is reflected among others in entire TC initiatives dedicated to knowledge and capacity building such as Guatemática (Barascout 2015: 32).

Strong collaboration between government institutions and both donor countries take the form of consultations (Japan) and the education of public administrators (Korea). Moreover, working together contributes to related institutional, policy and behavioural changes in the recipient country based on reflected practices (Roblero Morales 2017: 42; JICA 2018 [1]). With regards to the application of acquired knowledge, KOICA driven initiatives stand out based on initiated panel discussions and presentations fostering active knowledge sharing among interested stakeholders as well as governmental institutions (KOICA Guatemala 2018 [4]).

\section{ii. Use of Country Systems and Human Resources}

Both Korea and Japan officially committed to the DAC aim of untied aid. However, the percentage of untied aid, specifically as part of non-loan-based TC initiatives in Guatemala, remains dubious based on definitional interpretations on the Japanese side (OECD 2014: 60) as well as insufficient data provision on the Korean side (KOICA Guatemala 2018 [2]). Korea's commitment to completely untied TC initiatives is most notably cast in doubt by a recent loan-based TC offer made to modernise a harbour on Guatemala's east coast (El Periódico 2018). A comparison with Japanese loanbased TC initiatives in Guatemala indicates the increasing refrainment from tied aid on the Japanese side (JICA 2018 [6]).

The investigation highlights that project specific material is provided by both donor countries. Only basic amenities are contributed by Guatemala, and information on procurement sources within non loan-based TC projects remains unclear. The same applies for concrete data on the percentage of local human and material resources: contributions by donor countries and local human resources cover a large share of administrative tasks (Embajada de la República de Corea en Guatemala 2018; JICA 2018 [8]). 


\section{iii. Knowledge and Technology Transfer}

Both donor countries place emphasis on health, education and infrastructure in their TC initiatives with the aim of addressing specific Guatemalan developmental needs. Technology-enhancing cooperation initiatives are not a priority in Japan and Korea's approach in Guatemala, reflected in related development cooperation documents (JICA 2018 [3]; SEGEPLAN 2018 [1]: 3). On the other hand, initiatives based on knowledge exchange and skill transfer via delegated experts and volunteers enjoy great priority in both countries' development cooperation approaches (Barascout 2015: 47; KOICA Guatemala 2018 [2]).

It can be highlighted that Korea puts a comparatively stronger focus on transferring technological tools and systems alongside its TC initiatives (Roblero Morales 2017: 58), while Japanese efforts are comparatively more focused on knowledge transfer and exchanges fostering basic skills for future technological development (JICA 2018 [1]).

\section{iv. Domestic Revenue Generation}

By focusing on TC initiatives addressing fundamental Guatemalan needs, both countries aspire to extend nationally driven initiatives, encouraging the way out of recipient dependency (Roblero Morales 2017: 53; JICA 2018 [10]). As both donor countries only monitor TC initiatives to the point of ex post evaluation reports, a lack of relevant monitoring vis-à-vis long-term independence fostering measures can be pointed out (KOICA 2013; JICA 2018 [10]).

\section{Accountability and Transparency}

\section{i. Data Management and Reporting}

Data management and reporting enjoy great relevance in both donor countries' cooperation initiatives and are reflected in related efforts to publish project information. Both countries reflect the basic willingness and capacity to publish TC related information which typically comprises explanations on geographical focus, type and instruments, time frames, and expected results within evaluation reports (JICA 2018 [7]; KOICA Stats 2018). Korea, however, comparatively lags behind when it comes to sharing TC news, an approach better managed by Japan (JICA 2018 [5]).

Additionally, flaws can be found in Korea's ex post evaluation reports which are not only relatively scarce but also capture relevant project information based on the applied format less efficiently (KOICA 2018 [2]). Japan, on the other hand, manages well through a number of annual reports and yearly evaluation summaries to provide a complete and updated picture to relevant stakeholders (JICA 2018 [4]). Additionally, 
Japan recently published information on social and environmental impact, thus further fostering relevant reporting standards within TC (JICA 2018 [6]: 3-5).

\section{ii. Monitoring and Evaluation for Learning}

While monitoring and evaluation processes at the project level are qualitatively high based on related project standards that consider all stages of the project cycle, monitoring and evaluation processes at the institutional and national level show deficiencies in both donor countries (JICA 2018 [9]; OECD 2018 [3]: 17). Given these deficiencies contribute to a lack of expertise and capacity in M\&E processes, mitigating approaches have been adopted by the Japanese side to overcome related flaws by consulting external experts (OECD 2014: 72).

Knowledge sharing fostering long-term effects in development cooperation is integrated in M\&E project cycle related considerations by both countries (JICA 2010: 1; KOICA 2018 [3]). The lack of long-term follow-up reports following ex post evaluation reports impedes statements vis-à-vis the extent to which long-term knowledge generation in Guatemala is achieved from the M\&E initiatives (JICA 2018 [8]; KOICA 2018 [2]).

\section{iii. Transparency and Access to (Published) Information}

Japan and Korea's approaches towards transparency show differences based on the centrality of information provision as well as the regularity of information updates. The vast majority of Japanese TC-related information is provided on a JICA hub website (JICA 2018 [1]) with related strategic documents published by MOFA (2018 [3]). Access to Korean information is meanwhile more dispersed with information provided on multiple discrete platforms, making the accumulation of relevant information for stakeholders comparatively more difficult (KOICA 2018 [1]; ODA Korea 2018 [1]).

Assessing Japanese and Korean platforms overall, both donor countries' transparency and accessibility endeavours can be characterised by high comprehensiveness, offering back as well as forward-looking information. Efforts by Japan to provide timely news updates on TC initiatives can be considered greater compared to Korean platforms where project news is almost non-existent and ex post evaluation reports for completed initiatives are only sparsely available (JICA 2018 [2]; KOICA Guatemala 2018 [2]).

iv. Mutual Accountability and Joint Reviews

The investigation shows that both donor countries pursue review mechanisms within their TC approach, with Japan encouraging regular review meetings (JICA 2016 [2]: 
3) and Korea performing mid-term reviews with the recipient country (KOICA 2018 [2]). While Korea's initiated reviews are more project participant-based, Japan's review initiatives additionally include the governmental level (MSPAS 2018).

\section{Development Efficiency}

\section{i. Flexibility and Adaptation}

While both countries in principal display strong awareness for the need for flexibility and adaptability, deficiencies can be pointed out in regard to the related execution. In the case of Korea, the degree of contextual specificity for Guatemala is impeded by the lack of in-depth country analysis performed for non-core partner countries (ODA Korea 2018 [2]). Given both countries pursue a stand-alone as opposed to a programme-based project approach in Guatemala, the flexibility in the use of funds is impeded by the relatively short project running period (Development Finance International 2010: 7; OECD 2014: 52). While KOICA balances related flaws in flexibility and adaptability via the delegation of experts in charge of relevant project modifications (Roblero Morales 2017: 52), JICA implements mid-term reviews to encourage necessary adaptations (JICA 2010: 10).

Regarding the successful takeover of projects, a lack of evidence can be attested as no follow-up reports to ex post evaluation reports are available.

\section{ii. Coordination (Internal and External)}

Both donor countries have made continuous efforts in recent years to streamline coordination by fostering improved organisational structures. This has led to a tendency towards greater decentralisation and a growing focus on the establishment of local offices in recipient countries with the aim of greater responsiveness to recipient countries' local needs and conditions. Despite such organisational changes, significant progress is required before the self-reliant delegation of the local authority from headquarters becomes the norm (OECD 2014: 51; OECD 2018 [3]: 59).

Foreign projects in Guatemala are mandatorily coordinated in cooperation with the local governmental organisation SEGEPLAN (2018 [1]: 5). The level of integration of Guatemalan and Japanese or Korean organisations respectively is generally high, contributing to donor and recipient-sided coordination. However, while Japan coordinates its TC initiatives via a centralised agency in Guatemala with strong links to headquarters (JICA 2018 [2]), Korea's approach presents itself as more dispersed with multiple agencies interacting with the local authorities (OECD 2018 [3]: 21). 


\section{iii. Time and Cost Efficiency}

The evaluation of time and cost efficiencies reveals notable differences in both donor countries' approaches. While Japan and Korea face bureaucratic delays based on organisational structures (OECD 2018 [3]: 20), Japan has made efforts towards mitigating related problems based on restructuring within its main organisation. It has moved towards a more locally established organisation separated from headquarter structures (MOFA 2010) which contributes to enhanced cost and time-related transactions; this is reflected by budgeted time and cost frames in Guatemalan projects commonly being met (JICA 2016 [2]: 38). This clear assessment of cost and time-related matters within JICA's TC initiatives in Guatemala are enabled thanks to related standards of reporting which clearly outline relevant ratios and data in individual project evaluation reports as well as annual evaluation reports published by JICA (2018 [7]). In contrast, KOICA's evaluation reports for Guatemalan TC projects rely partially on qualitative means such as interviews with participants which lack comprehensiveness for interested stakeholders (KOICA 2018 [2]).

\section{Discussion}

\section{Similarities and Differences in Japan and Korea's Approaches}

As the preceding analysis shows, Japanese and Korean TC approaches are generally marked by several similarities fostered by a set of standards regarding what makes TC initiatives qualitatively high. This is most notably reflected in the shared official commitment to the importance of people-centred inclusivity, demand-drivenness, capacity building, knowledge and technology transfer, transparency and access to published information, solidarity and trust, as well as internal and external coordination through which both donor countries achieved strong results. In line with these factors, criteria such as multi-stakeholder participation, shared decisions and resources, use of country systems and resources, domestic revenue generation, monitoring and evaluation for learning, mutual accountability and joint reviews, as well as flexibility and adaptation must be pointed out. In regard to these criteria, both Japan and Korea's TC efforts are based on the same official values and quality commitments yet lack successful implementation in Guatemala. Lastly, the shared limited official commitment to the aspect of mutual benefit and low implementation by both donor countries can be highlighted.

Despite similar official quality standards and commitments in the field by KOICA and JICA, relatively greater gaps in implementation were identified in regard to nonconditionality, data management and reporting as well as time and cost efficiency criteria. 
As the preceding analysis shows, Japan obtained higher evaluations overall than Korea, except for the knowledge and technology transfer and capacity building categories. With regards to the majority of criteria evaluated, no grave differences in Japan and Korea's TC initiatives in Guatemala can be pointed out.

\section{Factors Accounting for Similarities and Differences}

With both donor countries sharing the same official commitments and values regarding most TC assessment quality criteria, assessed divergences in the implementation and application of relevant criteria in Guatemala by both countries are primarily found to stem from differences in reporting. Korea provides limited documentation about recipients beyond the scope of its so-called priority countries; reporting on Guatemala by KOICA is thus relatively scarce. The data management and reporting as well as the time and cost efficiency indicators illustrate comparatively bigger differences in evaluation results between both donor countries. The generally higher reporting standards displayed by Japan within the analysis additionally enforces the impact of comparatively less documentation by KOICA on initiatives in Guatemala and related influences on the outcomes within the analysis.

A second aspect is Japan's comparatively long-standing relations with Guatemala. This circumstance is most notably reflected in the solidarity and trust and mutual accountability and joint reviews criteria. The longer-established bonds between Japan and Guatemala are reflected in comparatively greater interaction on the political level.

These circumstances partially explain the stronger evaluations achieved by Japan in the preceding indicator and criteria analyses. Similar institutional and project related structures and approaches that also contribute to the aforementioned outcomes must be highlighted too. Most notably, similar organisational structures, the shared tendency towards a government-to-government approach, similar project cycle structures, as well as adherence to stand-alone as opposed to programme-based project approaches can be pointed out.

Common organisational structures can partially be explained due to mutual DAC membership and adherence to related standards. While Japan was one of DAC's founding members, Korea's time to align its ODA policies according to DAC standards was relatively limited since it joined DAC in 2010. Moreover, Japan was one of the leading donors in the international aid community in the 1990s, long before Korea's DAC membership in 2010, thus limiting DAC membership-based explanatory approaches (Kim 2017: 93). Japan's long-standing experience in TC has had a learning and simulation effect on Korea, contributing to the tendency of comparatively higher quality criteria-related evaluations in Japan's TC approach as opposed to Korea's. 


\section{Learning and Simulation Effects}

As Kondoh (2015: 33) argues, notable similarities between both countries' aid models can be derived from the fact that Korea's traditional aid model was initially constructed based on the Japanese layout. Displaying a mutual gain approach in its initial stages, the Japanese aid model was characterised by loans in the infrastructure sector targeted at facilitating Japanese foreign direct investment (FDI). Repayment of loans through exporting natural resources was a model adopted by Korea in its initial approach (Kondoh 2015: 32).

Japan's development approach in the following decades - namely the realisation of geo-economic interests under the DAC umbrella (Kondoh et al. 2010: 9)-was consulted a second time by Korea when confronted with preparations for DAC membership (Kondoh 2015: 33).

Kondoh (2015: 49) summarises the commonalities of Japan and South Korea in an Asian DAC aid model arguing that Asian DAC donors reflect commercial as well as humanitarian traits based on their position between Western DAC members and emerging donors. Summing up, it is argued that "Korea's experience of receiving aid from Japan and learning from Japan's implementation methods, both economic development strategies and practical knowledge about giving aid, influenced Korea's ODA policymaking and brought about similarities in the two donor countries' manner of providing ODA" (Kondoh 2012 in: Kim 2017: 92).

Limitations to the assimilation of both countries' aid models based on imitation and learning effects can be pointed out by a number of profound differences between both donor countries as outlined in this article's introduction. For instance, while Japan can be identified as one of the OECD-DAC's largest donors by volume over the years (OECD 2017), Korea has been recognised as the fifth largest contributor of Southern development aid prior to its DAC membership (Marx and Soares 2013). Korea is a newly industrialised country that only recently made the jump from an ODA receiver to a DAC member in 2010. Alongside the country's specially assigned role in SSDC discussions (Kondoh et al. 2010; Kondoh 2015), it can be questioned why greater differences were not identified in Japan and Korea's TC initiative approaches.

In order to answer this question, discussion results must be expanded to tackle the selected analytical framework and the criteria applied for the comparison of Japanese and Korean TC initiatives in Guatemala which simultaneously reflect traditional (North-South) and SSDC principles. 


\section{Assimilation of Traditional and South-South Cooperation Concepts: Initial Inconsistency within Development Cooperation Approaches}

The starting point to merger and assimilation discussions of development cooperation concepts as reflected in the applied analytical framework and related selected criteria is the notion of an initial inconsistency and blurriness within the traditional development cooperation concept - as represented by the DAC - and the SSDC approach.

With regards to its proclaimed differences partially derived from a wider scope of activities, SSDC is often presented by its advocates as a revolutionary new concept which is fundamentally different from traditional development cooperation approaches. It has consequently been argued that South-South Cooperation, Development Cooperation, SSDC, and ODA as defined by the DAC can be regarded as distinct concepts, with merely potential overlaps among them (SAIIA 2015: 12). However, as Sanahuja (2010: 19) points out, the validity of this assumption would go in line with the need for an entirely new analytical framework that aims to understand international development cooperation. Lastly, despite some pronounced differences in their approaches, South-South and traditional development cooperation rely on the same roots to explain the behaviour of states and other international actors within the framework of the international system and can be discussed using identical theories.

The traditional development cooperation approach as represented by the DAC has received criticism regarding a lack of clear boundaries drawn to alternative development cooperation concepts with increasing tendencies towards inconsistency displayed over recent years. International aid regimes were founded by Western communities (Rowland 2008 in: Kondoh 2015: 6); related principles, rules, and norms are thus mainly influenced by Western-based international organisations such as the World Bank, United Nations and the DAC (Kondoh 2015: 6). Most notably, the DAC has put considerable effort into the alignment of the aid-related strategies of its members by means of a number of ratified declarations (ibid.: 7). DAC aid definitions have been criticised as "shaped by the West's discursive as well as material dominance of the aid arena," resulting in the reluctance of aspiring emerging countries to adopt related definitions (Vaes and Huyse 2013: 21). The insufficient institutionalisation of the DAC - characterised by an aid regime limited to its members and a model that is neither uniformly articulated nor commonly shared - heightens the hesitation of Southern emerging powers to adopt the DAC system (ibid.: 7).

\section{Increasing Merging of Development Cooperation Concepts}

The previously identified inconsistency within traditional and SSDC concepts draws attention to the increasing drifting of DAC members towards aid modalities which were formerly strongly interconnected with the concept of South-South Cooperation-most notably the mixing of aid with commercial instruments in regard to TC. 
As Mawdsley (2017: 110) points out, the contribution in absolute and relative terms from non-DAC members is increasing, most notably their attractiveness to aid receivers as opposed to conditions-based aid. This has increased the incentive for DAC donors to reflect on firmly established principles such as refraining from mixing aid or pursuing mutual benefits based on opportunities. Competition in regard to contracts, access to resources, market share, as well as influence in the political sphere make the South-South model an increasingly viable option to Western players who are eager to secure their position in emerging markets (Carmody 2011 in: Mawdsley 2017: 112). The drifting of the DAC model towards South-South Cooperation modalities is characterised by Isenman and Shakow (2010 in: Gore 2013: 774) as a "schizophrenic" pairing comprised of the originally laid out model and rising engagement in global funds.

\section{The Merging Impact of High Level Fora on Aid Effectiveness}

As pointed out briefly in this article's theoretical section, the Fourth High Level Forum on Aid Effectiveness in Busan illustrates major development concept assimilation effects (Mawdsley 2017: 110-111) by constituting a double compromise (Gore 2013: 776):

1. The compromise between DAC members and Southern development cooperation partners

2. The compromise between the aim for a completed aid effectiveness agenda and progress beyond aid in favour of development cooperation effectiveness.

In particular, the compromise favouring development cooperation effectiveness in line with the new conceptual perspective of "Beyond Aid" can be pointed out (Gore 2013: 776; Janus et al. 2014: 4). This is most notably marked by the claim of ownership over aid (INTRAC 2012: 16), a focus by Northern as well as Southern players prior to the Busan meeting (SAIIA 2015: 25).

Based on the mutually influencing tendency of traditional and South-South Development concepts, Gore (2013: 774) concludes "the contrast between vertical (NorthSouth) and horizontal (South-South) models of partnership is in danger of being a caricature." The relative lack of conscious effort put into converging traditional North-South and South-South Cooperation patterns has resulted in the increasing endorsement of principles and values displaying major commonalities and reflecting a growing ideological challenge towards the hegemonic system (Tortora 2011:2).

Summing up, in line with the approach reflected in the applied NeST framework and the related indicators and criteria, it can be pointed out that North-South and South-South Cooperation must be regarded as complementary rather than mutually exclusive (Tortora 2011: 4). Referring back to the comparative case studies of 
Japanese and Korean TC approaches in Guatemala, the strong role which both donor countries display as representatives of the traditional and the SSDC concept must be highlighted. Korea - a former important actor within SSDC prior to the country's DAC membership in 2010 (Marx and Soares 2013) - is compared to Japan, one of the OECD-DAC's early members and largest donors (OECD 2017). The application of a traditional or South-South Cooperation inspired analytical framework that reflects respective principles prior to increased recent merging tendencies might have resulted in potentially greater differences in results. Gaps in respective priorities set within the different development cooperation concepts may have been identified. Particular criteria from the applied NeST framework - which reflect a mainly South-South Cooperation based approach such as mutual benefit and non-conditionality-illustrate concept-based differences in Japan and Korea's approach as they retain aspects of conflict among traditional and South-South Cooperation representatives. In the case of the mutual benefit criteria, Korea has only recently adapted its position in favour of greater DAC conformity. While Korea's "2017 ODA White Paper" remains silent about eventual mutual benefits attainable through development cooperation (ODA Korea 2017), Korea's ODA white paper published in 2014 still promotes the ideal of "Win-Win ODA" as a major guideline (ODA Korea 2014: 3), an approach which is still partially reflected in Korea's initiatives in Guatemala.

Overall, it can be concluded that by applying an analytical framework reflecting merging trends in traditional North-South and SSDC concepts, a mediating effect is exerted in regard to potential differences arising between both donor countries based on their different backgrounds. In the following section, a further aspect in support of the application of an analytical framework reflecting merged cooperation concepts is presented.

\section{Engagement in Triangular Cooperation}

Triangular cooperation - commonly comprising a DAC member donor and an emerging donor country providing mutual assistance to an emerging recipient country-is a relatively recent phenomenon with increasing relevance to development cooperation agendas (Ashoff 2010: 22). Aiming mostly for capacity building in the recipient countries, triangular cooperation is mainly performed in TC initiatives (ibid.: 23). Triangular cooperation can be regarded as a mutual learning process beyond distinct development cooperation concept boundaries given it requires the identification and respectful treatment of varying interests by all parties (Ashoff 2010: 22).

It can be argued that both Japan and Korea are key figures within triangular cooperation given their history and engagement. Japan is currently the leading DAC member engaged in triangular cooperation (Ashoff 2010: 22) and has supported triangular training programmes since as early as 1974 (Kitano 2014: 2). Korea has naturally become involved in the triangular cooperation approach based on the experience and 
networks which the country has acquired as a member of the South-South Cooperation community prior to its DAC membership (Marx and Soares 2013). Korea's specific development history further contributes to the manifestation of the country's role as a mediator among traditional North-South and SSDC interests, arguing that the country "can play a crucial role in bridging the gap between donor countries and developing partners by sharing their development experiences with the help of aid" (Jerve 2007: 8). Japan has also highlighted its position "as a bridge between the more traditional DAC donors and 'emerging' or newer donors" (Menocal and Denney 2011: 7) given its "distinctive voice" at times within the DAC. The country's role aligns with its own beliefs and viewpoints on effective TC approaches based on its long-standing engagement within the field of development cooperation as well as its position as a nonWestern OECD-DAC member with a distinct history and culture (Menocal and Denney 2011: 7).

Referring back to the identified similarities in Japanese and Korean TC initiatives in Guatemala, it can thus be argued that the similar approaches result from adherence to cooperation principles that foster the alignment of interests demanded by triangular engagements. As Ashoff (2010: 22) points out, mutually agreed aid effectiveness principles support successful triangular cooperation. The application of the NeST framework - based on commonly agreed principles of effective development cooperationand similar results in Japanese and Korean TC approaches illustrate both countries' commitment to internationally agreed development cooperation principles adhered to by traditional and Southern players. This aligns with Japan and Korea's shared aim of pursuing successful triangular cooperation.

\section{Conclusions}

As Piefer (2014: 6) points out, "development thinking often remains stuck in traditional patterns of hegemony of the North over the South," failing to address the challenges of today's increasingly multipolar world (ibid.: 27). Rather than losing oneself in discussions on whether traditional or Southern development cooperation approaches are morally and normatively preferable, a combination of both approaches should thus be pursued in order to avoid the domination of "hegemonic (realist) or counter-hegemonic (post-colonial) thinking" (Piefer 2014: 27) within development cooperation discourses. As Casoo (2014 in: Piefer 2014: 26) accordingly emphasises, "the future is probably a combination of traditional and non-traditional partners and partnerships that apply new and innovative approaches and modalities, and working together to strengthen human and institutional capacity for sustainable development, and to eradicate poverty and underdevelopment."

Having applied an analytical framework that implements this combined approach based on mutually agreed development cooperation principles reflecting traditional 
and SSDC concepts, this article takes into consideration this long-term focus in development and related TC, reflecting cooperation beyond conceptual restrictions. The similarities obtained as results in regard to Japanese and Korean TC initiatives in Guatemala thus also reflect a future-driven development cooperation approach borne by both donor countries - one that disregards organisational memberships and related boundaries.

\section{REFERENCES}

Ali, Murad. 2018. "Monitoring and Evaluation in South-South Cooperation: The Case of CPEC in Pakistan." German Development Institute Discussion Paper, 1, pp. 1-36.

Alonso, Jonathan and José Glennie. 2015. "What Is Development Cooperation?" Development Cooperation Forum Policy Brief, 1, pp. 1-5.

Ashoff, Guido. 2010. "Triangular Cooperation: Opportunities, Risks, and Conditions for Effectiveness." Online: https://openknowledge.worldbank.org/handle/10986/6081 (accessed: September 17, 2018).

Bandura, Romina and MacKenzie Hammond. 2019. A Demand-Driven Approach to Development. A CSIS Primer. Washington D.C.: Center for Strategic \& International Studies.

Barascout, Maria. 2015. "La Cooperación internacional de Japón hacia Guatemala en el ámbito educativo, caso Guatemática en el periodo 2009-2012.” M.A. thesis, Universidad Rafael Landívar, Guatemala.

Baumann, Max-Otto. 2018. "Mission Impossible? Country-level Coordination in the UN Development System.” German Development Institute Discussion Paper, 7, pp. 1-48.

Bergström, Lennart. 2002. "Methods for Capacity Development: A Report for Sida's Project Group “Capacity Development as a Strategic Question." SIDA Working Paper, 10, pp. 1-23.

Birdsall, Nancy and Homi Kharas. 2010. Quality of Official Development Assistance Assessment. Washington D.C.: Center for Global Development.

Bloomberg. 2018. "Emerging Markets Start 2018 with Politics Center Stage." Online: https://www.bloomberg.com/news/articles/2018-01-02/emerging-markets-start-2018-with-politics-and-inflation-in-focus] (accessed: May 24, 2018).

Buiter, Willem. 2005. "Country Ownership: A Term Whose Time Has Gone.” In Stefan Koeberle, Harold Bedoya, Peter Silarsky, and Gero Verheyen, eds., Conditionality Revisited Concepts, Experiences, and Lessons. Washington D.C.: The World Bank, pp. 27-33.

Business Insider. 2018. "China's Latest Triumph Over Taiwan Points to Its Growing Influence in the US's Neighborhood.” Online: http://www.businessinsider.com/china-influence-over-taiwan-in-latin-america-2018-5 (accessed: May 24, 2018).

Christensen, Zachary, Richard Nielsen, Daniel Nielson, and Michael Tierney. 2011. "Transparency Squared: The Effects of Donor Transparency on Aid Recipients' Corruption Levels.” International Political Economy Society Meeting Paper, pp. 1-43.

CID (Council for International Development). 2012. "Ownership: A Brief Overview of Ownership within Development." CID Fact Sheet, 8, pp. 1-2.

Coe, Jim and Juliette Majot. 2013. "Monitoring, Evaluation and Learning in NGO Advocacy:

Findings from Comparative Policy Advocacy.” MEL Review Project, pp. 1-67. 
Dahi, Omar and Firat Demir. 2017. "South-South and North-South Economic Exchanges: Does it Matter Who is Exchanging What and With Whom?" Journal of Economic Surveys, 31 (5), pp. 1449-1486.

Del Biondo, Karen. 2015. "Moving beyond a Donor-Recipient Relationship? Assessing Partnership in the Joint Africa-EU Strategy." KFG Working Paper, 63, pp. 1-30.

De Oliveira, Joana. 2017. "Paths for Developing South-South Cooperation: Monitoring and Evaluation Systems." BRICS Policy Center and South-South Cooperation Research and Policy Centre Report, pp. 1-44.

Development Finance International. 2010. "Republic of Korea (South Korea).” Country Profile Report, pp. 1-11.

El Periódico. 2017. "Banco Industrial obtiene línea de crédito por US\$30 millones con Korea Eximbank.” Online: https://elperiodico.com.gt/inversion/2017/04/04/banco-industrial-obtienelinea-de-credito-por-us30-millones-con-korea-eximbank/ (accessed: June 29, 2018).

El Periódico. 2018. "Corea del Sur ofrece crédito para Puerto Santo Tomás." Online: https://elperiodico.com.gt/inversion/2017/10/05/corea-del-sur-ofrece-credito-para-puerto-santo-tomas/ (accessed: June 27, 2018).

Embajada de Japón en Guatemala. 2018. "Relaciones Bilaterales: Relaciones entre Japón y Guatemala.” Online: http://www.gt.emb-japan.go.jp/relaciones_bilaterales1.htm\#fechas (accessed: June 3, 2018).

Embajada de la República de Corea en Guatemala. 2018. "[Noticias recientes sobre KOICA] Información sobre Proyectos." Online: http://overseas.mofa.go.kr/gtes/brd/m_5605/view.do?seq=697740\&srchFr=\&srchTo=\&srchWord $=\&$ srchTp $=\&$ multi_itm_seq $=0 \& i t m \_s e q \_1=0 \& i t m \_s e q \_2=0 \&$ company_cd=\&company_nm=\&page=9 (accessed: June 10, 2018).

European Commission. 2009. "Making Technical Cooperation More Efficient." Tools and Methods Series: Guidelines, 3, pp. 1-156.

Eyben, Rosalind. 2008. "Power, Mutual Accountability and Responsibility in the Practice of International Aid: A Relational Approach.” IDS Working Paper, 305, pp. 1-51.

Faure, Anaïs. 2016. "South Korea's Role in East Asia-Latin America Cooperation." Online: https://thediplomat.com/2016/10/south-koreas-role-in-east-asia-latin-america-cooperation/ (accessed: May 3, 2018).

FIDC (Forum for Indian Development Cooperation). 2014. "Features of South-South Cooperation and Global Dynamics." FIDC Policy Brief, 1, pp. 1-4.

Frontera. 2016. "Why South Korea Remains Classified as an Emerging Market." Online: https://frontera.net/news/asia/emerging-markets-investment-in-south-korea-a-market-withcharacteristics-similar-to-developed-markets/ (accessed: May 24, 2018).

Garbarino, Sabine and Jeremy Holland. 2009. "Quantitative and Qualitative Methods in Impact Evaluation and Measuring Results." GSD-RC Governance and Social Development Resource Center Issues Paper, pp. 1-41.

Godfrey, Martin, Chan Sophal, Toshiyasu Kato, Long Piseth, Pon Dorina, Tep Saravy, Tia Savora, and So Sovannarith. 2002. "Technical Assistance and Capacity Development in an Aid-Dependent Economy: The Experience of Cambodia." World Development, 30 (3), pp. 355-373.

Gore, Charles. 2013. "The New Development Cooperation Landscape: Actors, Approaches, Architecture." Journal of International Development, 25, pp. 769-786.

Gray, Kevin and Barry Gills. 2016. "South-South Cooperation and the Rise of the Global South." Third World Quarterly, 37 (4), pp. 557-574.

Haider, Huma. 2008. "Demand-Driven Technical Assistance." GSD RC Research Report, pp. 113. 
Holzapfel, Sarah. 2014. "The Role of Indicators in Development Cooperation: An Overview Study with a Special Focus on the Use of Key and Standard Indicators." German Development Institute Studies, pp. 1-252.

IMF (International Monetary Fund). 2016. "Achieving More Equality and Stronger Growth in Guatemala." IMF Dialogo al Fondo, pp. 1-3.

Infile. 2018. "Convenios." Online: https://leyes.infile.com/index.php?id=145\&pagina_publicaciones=0\&tipo_documento=\&texto_buscador=corea (accessed: August 15, 2017).

INTRAC (International Training and Research Center). 2012. "The Busan Partnership: Implications for Civil Society." Policy Briefing Paper, 29, pp. 1-16.

Janus, Heiner, Klingebiel, Stephan, and Sebastian Paulo. 2014. "Beyond Aid: A Conceptual Perspective on the Transformation of Development Cooperation." CDDRL Working Paper, 12, pp. $1-17$.

Jerve, Alf. 2007. “Asian Models for Aid: Is There a Non-Western Approach to Development Assistance?" CMI Report, 12, pp. 1-9.

JICA (Japan International Cooperation Agency). 2010. "New JICA Guidelines for Project Evaluation.” JICA Evaluation Department Report, pp. 1-83.

JICA (Japan International Cooperation Agency). 2016 [1]. "El inicio del Proyecto- La implementación del primer Comité de Coordinación Conjunta (CCC).” Online: https://www.jica.go.jp/project/spanish/guatemala/004/news/general/160627.html (accessed: August 13, 2018).

JICA (Japan International Cooperation Agency). 2016 [2]. JICA Annual Evaluation Report 2016. Tokyo: Japan International Cooperation Agency.

JICA (Japan International Cooperation Agency). 2018 [1]. "Prioridades de Cooperación.” Online: https://www.jica.go.jp/guatemala/espanol/activities/activity01.html (accessed: June 6, 2018).

JICA (Japan International Cooperation Agency). 2018 [2]. "Guatemala.” Online: https://www.jica.go.jp/guatemala/english/index.html (accessed: June 6, 2018).

JICA (Japan International Cooperation Agency). 2018 [3]. "Map of JICA Major Projects in Guatemala." Online: https://www.jica.go.jp/guatemala/english/activities/index.html (accessed: June 6, 2018).

JICA (Japan International Cooperation Agency). 2018 [4]. "Result of Ex-Post Evaluation Report." Online: https://www2.jica.go.jp/en/evaluation/index.php?anken=\&country1=Guatemala\&area $2=\&$ country $2=\&$ area $3=\&$ coun try $3=\&$ field $1=\&$ field $2=\&$ field $3=\&$ start_from $=\&$ start_to $=\&$ search $=$ Search $($ accessed: June 6 , 2018).

JICA (Japan International Cooperation Agency). 2018 [5]. “Guatemala: List of Projects.” Online: https://www.jica.go.jp/project/english/area/c_america/228_1.html (accessed: June 6, 2018).

JICA (Japan International Cooperation Agency). 2018 [6]. “ODA Loan Project Data.” Online: https://www2.jica.go.jp/en/yen_loan/index.php (accessed: June 15, 2018).

JICA (Japan International Cooperation Agency). 2018 [7]. "Resumen del Proyecto.” Online: https://www.jica.go.jp/project/spanish/guatemala/004/outline/index.html (accessed: August 13, 2018).

JICA (Japan International Cooperation Agency). 2018 [8]. “Ex-post Evaluation Report.” Online: https://www2.jica.go.jp/en/evaluation/index.php?anken=Guatemala\&area1=Latin+America\&country $1=\&$ area $2=\&$ country $2=\&$ area $3=\&$ coun try $3=\&$ field $1=\&$ field $2=\&$ field $3=\&$ start_from $=\&$ start_to $=\&$ fiscal_from $=\&$ fiscal_to=\&search=Search (accessed: August 15, 2018). 
JICA (Japan International Cooperation Agency). 2018 [9]). "Operations Evaluation in JICA.” Online: https://www.jica.go.jp/english/our_work/evaluation/about.html] (accessed: August 15, 2018).

JICA (Japan International Cooperation Agency). 2018 [10]). “Technical Cooperation Projects." Online: https://www.jica.go.jp/english/our_work/types_of_assistance/tech/projects/index.html (accessed: September 9, 2018).

JICA (Japan International Cooperation Agency). 2018 [11]). "Programa de Co-creación de Conocimientos." JICA Programme Report, pp. 1-15.

JICA (Japan International Cooperation Agency). 2018 [12]). "Public-Private Partnerships." Online: https://www.jica.go.jp/english/our_work/types_of_assistance/partnership/index.html (accessed: September 12, 2018).

Jordhus-Lier, David, Marit Haug, and Hari Regmi. 2009. "Demand-Driven Governance. An Analysis of the Interventions of International Aid Agencies." NIBR Working Paper, 118, pp. 1-39.

Jung, Jione, Yul Kwon, Jisun Jeong, Sukyung Park, and Jooyoung Lee. 2011. "South-South and Triangular Cooperation: Trends and Implications for Korea: Summary." Online: http://www.kiep.go.kr/eng/sub/view.do?bbsId=policyAnalyses\&nttId=185581 (accessed: May 24, 2018).

Kharas, Homi. 2013. "Transparency: Changing the Accountability, Engagement, and Effectiveness of Aid." In Homi Kharas, Koji Makino, and Woojin Jung, eds., Catalyzing Development: A New Vision for Aid. Washington D.C.: Brookings Institution Press, pp. 233-259.

Kim, Hyo-Sook. 2017. "Poverty Reduction and ODA Policymaking in Japan and South Korea." Journal of Inquiry and Research, 105, pp. 91-108.

King, Cheryl. 2014. "Partnership Effectiveness Continuum: A Research-Based Tool for Use in Developing, Assessing, and Improving Partnerships.” EDC Report, pp. 1-21.

Kitano, Naohiro. 2014. "Japan's Experiences on South-South and Triangular Cooperation." Online: https://www.unescap.org/sites/default/files/3-2_Kitano.pdf (accessed: September 17, 2018).

KOICA (Korea International Cooperation Agency). 2011. "Ex-Post Evaluation Report for KOICA Community Development Project for the Resettled Population in Guatemala." Online: http://www.koica.go.kr/english/resources/Evaluation/Evaluation_Reports/index.html] (accessed: June 17, 2018).

KOICA (Korea International Cooperation Agency). 2013. "Ex-post Evaluation Report on the Program for the Improvement of Maternal and Child Health in Chimaltenango." Online: http://www.koica.go.kr/english/resources/Evaluation/Evaluation_Reports/index.html (accessed: June 17, 2018).

KOICA (Korea International Cooperation Agency). 2016. “Annual Report 2016.” Online: http://www.koica.go.kr/english/resources/annual_reports/index.html (accessed: June 17, 2018).

KOICA (Korea International Cooperation Agency). 2018 [1]. "Korea International Cooperation Agency." Online: http://www.koica.go.kr/english/main.html (accessed: June 18, 2018).

KOICA (Korea International Cooperation Agency). 2018 [2]. "Evaluation Report." Online: http://www.koica.go.kr/english/resources/Evaluation/Evaluation_Reports/index.html (accessed: June 17, 2018).

KOICA (Korea International Cooperation Agency). 2018 [3]. “Type of Evaluation.” [Online: http://www.koica.go.kr/english/resources/Evaluation/Type_of_evaluation/index.html] (accessed: August 15, 2018).

KOICA Guatemala. 2018 [1]. "Misión de KOICA.” Online: http://www.koicabeca.org.gt/quienessomos.html (accessed: June 13, 2018). 
KOICA Guatemala. 2018 [2]. “Cooperación en Guatemala.” Online: http://www.koicabeca.org.gt/koica-guatemala.html (accessed: June 13, 2018).

KOICA Guatemala. 2018 [3]. "Estrategia para la Cooperación de KOICA." Online: http://www.koicabeca.org.gt/index.html (accessed: June 19, 2018).

KOICA Guatemala. 2018 [4]. "Intercambio de Conocimientos." Online: http://www.koicabeca.org.gt/intercambio-de-conocimientos.html (accessed: June 20, 2018).

KOICA Guatemala. 2018 [5]. "Seminars.” Online: http://www.koicabeca.org.gt/seminarios.html (accessed: June 21, 2018).

KOICA Guatemala. 2018 [6]. “Actividades de Voluntariado.” Online: http://www.koicabeca.org.gt/actividades-de-voluntariado.html (accessed: June 21, 2018).

KOICA Stats. 2018. "KOICA Statistical Service.” Online: http://stat.koica.go.kr/ipm/os/acms/smrizeBsrList.do?lang=en (accessed: June 17, 2018).

Kondoh, Hisato. 2012. “Korea's Pathway from Recipient to Donor: How Does Japan Matter?” In J. Sato and Y. Shimomura, eds., The Rise of Asian Donor: Japan's Impact on the Evolution of Emerging Donors. Routledge: London, pp. 133-154.

Kondoh, Hisato. 2015. "Convergence of Aid Models in Emerging Donors? Learning Processes, Norms and Identities, and Recipients." JICA Working Paper, 106, pp. 1-60.

Kondoh, Hisato, Takaaki Kobayashi, Hiroaki Shiga, and Jin Sato. 2010. "Diversity and Transformation of Aid Patterns in Asia's 'Emerging Donors." JICA Working Paper, 21, pp. 1-78.

Lucas, Brian. 2013. "Current Thinking on Capacity Development." GSDRC Research Report, pp. $1-13$.

Maggiorelli, Lorenzo. 2017. "Chinese Aid to Latin America and the Caribbean: Evolution and Prospect.” ELACID Artículo Resultado de Investigación, pp. 28-50.

Marx, Axel and Jadir Soares. 2013. "South Korea's Transition from Recipient to DAC Donor: Assessing Korea's Development Cooperation Policy.” International Development Policy, 4 (2), pp. 107-142.

Mawdsley, Emma. 2012 [1]. "The Changing Geographies of Foreign Aid and Development Cooperation: Contributions from Gift Theory." Transactions of the Institute of British Geographers New Series, 37 (2), pp. 256-272.

Mawdsley, Emma. 2012 [2]. From Recipient to Donors: Emerging Powers and the Changing Development Landscape. London: Zed Books.

Mawdsley, Emma. 2017. "Development Geography 1: Cooperation, Competition and Convergence between 'North' and 'South." Progress in Human Geography, 41 (1), pp. 108-117.

McGee, Rosemary. 2013. "Aid Transparency and Accountability: 'Build it and They'll Come?"” Development Policy Review, 31, pp. 107-124.

Menocal, Alina and Lisa Denney. 2011. "Informing the Future of Japan's ODA. Part One: Locating Japan's ODA within a Crowded and Shifting Marketplace." ODI Report, pp. 1-42.

MFDR (Managing for Development Results). 2007. "Monitoring and Evaluation: Enhancing Development Results." Third International Roundtable on Managing for Development Results in Hanoi, pp. 1-9.

MOFA (Ministry of Foreign Affairs of Japan). 2010. “Japan's Official Development Assistance White Paper.” Online: https://www.mofa.go.jp/policy/oda/white/2010/html/honbun/b2/s2_3_2.html (accessed: September 8, 2018).

MOFA (Ministry of Foreign Affairs of Japan). 2018 [1]. "Official Development Assistance." Online: http://www.mofa.go.jp/policy/oda/cooperation/anniv50/pamphlet/progress1.html (accessed: May 24, 2018). 
MOFA (Ministry of Foreign Affairs of Japan). 2018 [2]. "Country Assistance Policy for Respective Countries." Online: https://www.mofa.go.jp/policy/oda/assistance/country2.html (accessed: June 15, 2018).

MOFA (Ministry of Foreign Affairs of Japan). 2018 [3]. "Japan-Guatemala Relations (Basic Data).” Online: https://www.mofa.go.jp/region/latin/guatemala/data.html (accessed: September 11, 2018).

Montinola, Gabriella. 2007. "When Does Aid Conditionality Work?" Studies in Comparative International Development, 45 (3), pp. 358-438.

MSPAS (Ministerio de Salud Pública y Asistencia Social). 2018. "MSPAS: Proyecto de cooperación de JICA muestra avances en su primer año de acción en Quiché.” Online: http://www.mspas.gob.gt/index.php/noticias/noticias-mspas/item/317-mspas-proyecto-decooperacion-de-jica-muestra-avances-en-su-primer-ano-de-accion-en-quiche (accessed: $\mathrm{Au}$ gust 13, 2018).

Narasaiah, Lakshmi. 2003. The Role of Micro Credit and NGOs in Economic Development. New Delhi: Discovery Publishing House.

Naylor, William. 2017. "A Shifting Trade Landscape in Latin America Favors China and Globalization.” Online: https://theglobalamericans.org/2017/07/shifting-trade-landscape-latin-america-favors-china-globalization/ (accessed: May 24, 2018).

ODA Korea. 2014. Korea's ODA White Paper. Seoul: CIDC.

ODA Korea. 2017. Korea's ODA White Paper. Seoul: CIDC.

ODA Korea. 2018 [1]. "Korea Official Development Assistance." Online: http://www.odakorea.go.kr/ez.main.ODAEngMain.do (accessed: June 9, 2018).

ODA Korea. 2018 [2]. "Country Partnership Strategy.” Online: http://www.odakorea.go.kr/eng.policy.CountryPartnershipStrategy.do (accessed: June 10, 2018).

OECD (Organisation for Economic Co-operation and Development). 2006. "Successful Partnerships: A Guide." OECD LEED Forum on Partnerships and Local Governance, pp. 1-36.

OECD (Organisation for Economic Co-operation and Development). 2014. OECD Development Co-operation Peer Reviews: Japan 2014. Paris: OECD Publishing.

OECD (Organisation for Economic Co-operation and Development). 2017. "Development Aid Rises Again in 2016." OECD Summary Report, pp. 1-9.

OECD (Organisation for Economic Co-operation and Development). 2018 [1]. "Paris Declaration and Accra Agenda for Action." Online: http://www.oecd.org/dac/effectiveness/parisdeclarationandaccraagendaforaction.htm (accessed: July 15, 2018).

OECD (Organisation for Economic Co-operation and Development). 2018 [2]. "DAC Member Profile: Korea." Online: http://www.oecd.org/dac/korea.htm (accessed: May 28, 2018).

OECD (Organisation for Economic Co-operation and Development). 2018 [3]. OECD Development Cooperation Peer Reviews: Korea 2018. Paris: OECD Publishing.

OECD (Organisation for Economic Co-operation and Development). 2018 [4]. "DAC Members." Online: http://www.oecd.org/dac/dacmembers.htm (accessed: May 5, 2018).

Oxfam (Oxford Committee for Famine Relief). 2012. "Busan in a Nutshell: What next for the Global Partnership for Effective Development Cooperation?” Oxfam Briefing Note, pp. 1-14.

Park, Kyung Ryul. 2017. "An Analysis of Aid Information Management Systems (AIMS) in Developing Countries: Explaining the Last Two Decades." Hawaii International Conference on System Sciences Paper, pp. 2580-2589.

Piefer, Nadine. 2014. "Triangular Cooperation: Bridging South-South and North-South Cooperation? Workshop on South-South Development Cooperation Paper, pp. 1-31.

Poate, Derek. 1997. "Measuring and Managing Results: Lessons for Development Cooperation/Performance Management.” SIDA Joint Evaluation, pp. 1-97. 
Roblero Morales, Sindy. 2017. “Análisis de la Cooperación Internacional Coreana (KOICA) a partir del apoyo técnico económico a los programas de productividad y desarrollo en Guatemala." M.A. thesis, USAC Escuela de Ciencia Política, Guatemala.

Rocha Menocal, Alina and Leni Wild. 2012. "Where Can Japanese Official Development Assistance Add Value?" Project Briefing, 71, pp. 1-4.

Rosero Moncayo, Gabriella and Diego Zorilla. 2013. "Measuring the Effectiveness of Development Cooperation at the Local Level." UNDP Report, pp. 1-80.

SAIIA (South African Institute of International Affairs). 2015. "Developing a Conceptual Framework for South-South Cooperation.” SAIIA Working Document, pp. 1-58.

SAIIA (South African Institute of International Affairs). 2017. "A Monitoring and Evaluation Framework for South-South Cooperation.” SAIIA Working Paper March, pp. 1-28.

Sanahuja, José. 2010. "Post-Liberal Regionalism: S-S Cooperation in Latin America and the Caribbean." In Roy Rathin and Melissa Andrade, eds., South-South Cooperation. The Same Old Game or a New Paradigm? New York: UNDP Poverty in Focus, 20, pp. 17-19.

SEGEPLAN (Secretaría de Planificación y Programación de la Presidencia). 2018 [1]. "Fuentes bilaterales." Online: http://www.segeplan.gob.gt/nportal/index.php/bibliotecadocumental/tematica/publicaciones-cooperacion-internacional/category/105-fuentes-bilaterales (accessed: June 7, 2018).

SEGIB (Secretaría General Iberoamericana). 2010. "Report on South-South Cooperation in IberoAmerica.” SEGIB Studies, 5, pp. 1-83.

Selbervik, Hilde. 1999. "Aid and Conditionality: The Role of the Bilateral Donor: A Case Study of Norwegian-Tanzanian Aid Relationship.” Online: https://www.oecd.org/countries/tanzania/35178610.pdf (accessed: August 14, 2018).

The Asia Foundation. 2012. "Emerging Asian Approaches to Development Cooperation." Online: https://asiafoundation.org/resources/pdfs/EmergingAsianApproachestoDevelopmentCooperationConferencePapers.pdf (accessed: August 16, 2018).

The Diplomat. 2018. "South-Korea's Role in East Asia- Latin America Cooperation.” Online: https://thediplomat.com/2016/10/south-koreas-role-in-east-asia-latin-america-cooperation/ (accessed: September 11, 2018).

The World Bank. 2018. "The World Bank in Guatemala.” Online: http://www.worldbank.org/en/country/guatemala/overview (accessed: May 24, 2018).

Tortora, Piera. 2011. "Common Ground between South-South and North-South Cooperation Principles." OECD Development Co-operation Directorate Issue Brief, pp. 1-4.

Uh, Soo Bong and Roknuzzamn Siddiky. 2017. "Does Development Aid Work? Improving Aid Effectiveness in International Development Cooperation Efforts." Bangladesh e-Journal of Sociology, 14 (2), pp. 120-142.

UN (United Nations). 2014. "South-South Development Cooperation.” UN Background Note, pp. $1-4$.

UNCTAD (United Nations Conference on Trade and Development). 2014. "Transfer of Technology and Knowledge Sharing for Development: Science, Technology and Innovation Issues for Developing Countries." UNCTAD Report, pp. 1-71.

UNCTAD (United Nations Conference on Trade and Development). 2015. "Global Value Chains and South-South Trade. Economic Cooperation and Integration among Developing Countries." UNCTAD Report, pp. 1-56.

UNDESA (United Nations Department of Economic and Social Affairs). 2018. "National Mutual Accountability and Transparency in Development Cooperation: Study on the Findings of the Fifth DCF Survey." ECOSOC Development Cooperation Forum, pp. 1-32. 
UNDP (United Nations Development Program). 2009. "Handbook on Planning, Monitoring and Evaluating for Development Results.” UNDP Handbook, pp. 1-232.

UNDP (United Nations Development Program). 2015. "Guatemala Launches National Development Plan Mainstreaming Poverty-Environment.” Online: http://www.unpei.org/latestnews/guatemala-launches-national-development-plan-mainstreaming-poverty-environment (accessed: June 20, 2018).

UNISDR (The United Nations Office for Disaster Risk Reduction). 2013. "Monitoring and Evaluation Framework." UNISDR Publication Geneva, pp. 1-26.

Vaes, Sarah. and Huib Huyse. 2013. "New Voices on South-South Cooperation between Emerging Powers and Africa: African Civil Society Perspectives." KU Leuven Research Paper, pp. 178.

Van de Looy, Judith. 2006. “Africa and China: A Strategic Partnership?” ASC Working Paper, 67, pp. 1-28.

Wallach, Stefanie, Gregory Gleed, Emma Newbatt, and Jessica Shearer. 2017. "IDSI Monitoring, Evaluation and Learning Framework.” IDSI Post-Consultation Report, pp. 1-69.

Watson, David. 2006. "Monitoring and Evaluation of Capacity and Capacity Development." ECDPM Discussion Paper, 58B, pp. 1-32.

\section{ABBREVIATIONS}

$\begin{array}{ll}\text { BRICS } & \text { Brazil, Russia, India, China, South Africa } \\ \text { DAC } & \text { Development Assistance Committee } \\ \text { FDI } & \text { Foreign Direct Investment } \\ \text { JICA } & \text { Japan International Cooperation Agency } \\ \text { KOICA } & \text { Korea International Cooperation Agency } \\ \text { MOFA } & \text { Ministry of Foreign Affairs of Japan } \\ \text { M\&E } & \text { Monitoring and Evaluation } \\ \text { NeST } & \text { Network of Southern Think Tanks } \\ \text { NGO } & \text { Non-governmental Organization } \\ \text { NSC } & \text { North-South Cooperation } \\ \text { ODA } & \text { Official Development Aid } \\ \text { OECD } & \text { Organisation for Economic Co-operation and Development } \\ \text { SAIIA } & \text { South African Institute of International Affairs } \\ \text { SEGEPLAN } & \text { Secretaría de Planificación y Programación de la Presidencia } \\ \text { SSC } & \text { South-South Cooperation } \\ \text { SSDC } & \text { South-South Development Cooperation } \\ \text { TC } & \text { Technical Cooperation }\end{array}$

